HTTP://DX.DOI.ORG/10.12775/SZHF.2016.048

\author{
ANDRZEJ GLIŃSKI \\ Moskiewski Państwowy Uniwersytet Regionalny, Moskwa, Rosja \\ A.v.GLINSKY@GMAIL.COM

\section{„Tranzytywna” hermeneutyka tego, co polityczne (Hannah Arendt i Martin Heidegger) $^{*}$}

Aby uchwycić nowatorski wkład Hannah Arendt do współczesnego myślenia o polityce, który uwidacznia się w jej specyficznym rozumieniu tradycji historyczno-politycznych i wciąż wywiera wpływ na nasz ogląd totalitaryzmu, należy uwzględnić kontekst historyczno-filozoficzny, w jakim tworzyła ona swoją koncepcję. Kontekst ten pozwoli nam opisać to, w jaki sposób hermeneutyka polityki Arendt odbiega od idei głoszonych przez jej filozoficznych nauczycieli, w szczególności Karla Jaspersa i Martina Heideggera. Dla jasności wywodu odwołamy się do artykułu Rozumienie a Polityka ${ }^{1}$

* „Myślenie Heideggera miało tak decydujący udział w kształtowaniu duchowego oblicza naszego stulecia. Myślenie to ma swoją dociekającą właściwość, która - gdyby ją chciano wyrazić w formie lingwistycznej - polega na przechodnim użyciu czasownika »myśleć«. Heidegger nigdy nie myśli »o« czymś; on myśli coś. W tej całkowicie niekomplemencyjnej czynności dociera do głębin, nie po to jednak, by odkrywać, a już w żadnym wypadku, by wydobywać na światło dzienne jakieś ostateczne, niezachwiane podstawy. Raczej pozostaje uporczywie tam, w głębi, by wytyczać drogi i znaczyć "ścieżki «". H. Arendt, Ludzie w mrocznych czasach. Martin Heidegger kończy osiemdziesiąt lat, Gdańsk 2013, s. 176.

${ }^{1}$ H. Arendt, Rozumienie a Polityka, przeł. Józef Sieradzki, „Literatura na Świecie”, nr 6 (167), Warszawa 1985, s. 141. 
i przeanalizujemy podstawowe założenie metodologiczne Hannah Arendt wyrażone w pojęciu „przed-rozumienia”. Za pomocą tego pojęcia filozofka rozwija swoją koncepcję, w której twórczo kontynuuje egzystencjalno-fenomenologiczną ontologię wczesnego Heideggera (bez powoływania się na niego). Następnie spróbujemy zinterpretować kategorię „początku”, która ma tu węższe znaczenie niż w jej rozprawie Korzenie totalitaryzmu.

Artykuł ten poświęcony jest zatem analizie pojęcia „wstępnego rozumienia" (preliminary understanding) i stanowi próbę odtworzenia i wyjaśnienia hermeneutyki Arendt. Celowo używam tutaj terminu „hermeneutyka”, chociaż sama Arendt prawie nigdy nie stosowała go w swojej dojrzałej twórczości, a ponadto unikała odniesień do tradycji filozoficznej, z której wyrosła. Na początku zrekonstruujemy główne idee zawarte w artykule Rozumienie a polityka:

„Wiedza i rozumienie nie są tym samym, choć są ze sobą powiązane. Rozumienie opiera się na wiedzy, a wiedza nie może się rozwijać bez wstępnego intuicyjnego rozumienia. Wstępne rozumienie demaskuje totalitaryzm jako despotyzm; przesądza o tym, że nasza walka jest walką o wolność”2.

Wydaje się, że Arendt chce powiedzieć nam, żebyśmy nie traktowali dosłownie, dogmatycznie wskazanego w cytacie przeciwstawiania „wiedzy” i "rozumienia”, które wywodzi się z diltheyowskiej opozycji „rozumienia” i „wyjaśniania”: w rzeczywistości wiedza i rozumienie nie przeciwstawiają się sobie, ale są ze sobą ściśle „powiązane”. Z drugiej strony zaś, nie należy ich jednak utożsamiać, ponieważ - jak nowatorsko pokazuje Artendt - w relacji pomiędzy wiedzą a rozumieniem ujawnia się głęboka różnica między nimi. Innymi słowy Arendt „oświetla” zasadniczą różnicę pomiędzy dwoma ontologicznymi obszarami doświadczenia - pomiędzy doświadczeniem społeczno-historycznym a doświadczeniem w sensie matematycznego przyrodoznawstwa (to znaczy, w rozumieniu „filozofii przyrody”, jak wyraziła się Arendt w wywiadzie telewizyjnym z $1964 \mathrm{r}^{3}{ }^{3}$. Ponadto, co jest najistotniejsze, Arendt pragnie nam przekazać, że ściśle naukowa, obiektywna wiedza nie wyczerpuje całej problematyki poznania, ponieważ nie jest autonomiczna, nie jest wolna od zewnętrznych, wstępnych przesłanek czy „warunków możliwości”. Wiedza naukowa (albo poznanie) nie może być „czysta”, dlatego że

${ }^{2}$ H. Arendt, Rozumienie a polityka..., dz. cyt., s. 141.

${ }^{3} \mathrm{~W}$ angielskiej translacji wywiad ten, przeprowadzony w telewizji RFN 28.10.1964 r., opublikowano w książce Arendt, Essays in Understanding, 1930-1954..., dz. cyt. [16, z. 1-23]. 
sama opiera się na czymś poza sobą, a mianowicie - na wstępnym, niewyartykułowanym [intuicyjnym] rozumieniu. Co jednak właściwie oznacza owa teza o braku autonomii wiedzy naukowej?

Przede wszystkim pojęcie to związane jest $\mathrm{z}$ "hermeneutyką polityczną" Arendt, a w szczególności $\mathrm{z}$ podstawowym zagadnieniem „rozumienia”. Trudność związana $\mathrm{z}$ tym pojęciem polega na tym, że powinno ono umożliwić naukowy „sąd” o totalitaryzmie, o totalitarnym myśleniu i o świecie, w którym spowodowane przezeń okrucieństwa stają się najprawdziwszą rzeczywistością, pozostając zarazem czymś całkowicie nie do pomyślenia, niewspółmiernym ludzkiemu rozumieniu. Chodziłoby jednak o to, żeby sąd ten zachował związek z „oceną”, żeby nie był neutralnym, lecz wartościującym sądem (judgment). Ważne jest również to, żeby zorientować się, jaka jest istota „wstępnego rozumienia”, które poprzedza „krytyczny”, „artykułowany” sąd. W tym celu odniesiemy się do obszerniejszego fragmentu z artykułu Rozumienie a polityka:

Rozumienie poprzedza wiedzę i następuje po niej. Wstępne rozumienie, które stoi u podstaw wszelkiej wiedzy, i prawdziwe rozumienie, które wykracza poza nią, mają jedną wspólną właściwość: nadają wiedzy znaczenie. Opis historyczny i analiza polityczna nie są w stanie udowodnić, że istnieje coś takiego jak natura czy istota rządów totalitarnych, po prostu dlatego, że naturę mają rządy monarchiczne, republikańskie, tyrańskie czy despotyczne. Istnienie tej szczególnej natury zakłada wstępne rozumienie, na którym opiera się wiedza. Wstępne rozumienie przenika zaś w sposób oczywisty, ale bez przenikliwości krytycznej, całą terminologię i słownictwo, które służą do opisania tej natury. Prawdziwe rozumienie zawsze nawiązuje do sądów i uprzedzeń poprzedzających ściśle naukowe dociekanie i nim kierujących. Nauka może tylko oświecać, ale nigdy nie będzie w stanie uzasadnić przy użyciu dowodów, ani też obalić owego niekrytycznego „wstępnego rozumienia”, które stanowi jej punkt wyjścia ${ }^{4}$.

Powyższe stwierdzenie, jak sądzę, okaże się dla nas naprawdę „znaczące” (w sensie nadanym przez Arendt), jeśli nie będziemy go odnosić do oceny w znaczeniu osobistego sądu, który wydawany jest z „pozahistorycznej” perspektywy. Współczesny historyk filozofii zachodniej nie powinien mieć trudności z uchwyceniem przebiegu i sposobu myślenia Arendt o „wstępnym rozumieniu" - heideggerowskim par excellence. Pojęcie to występuje

${ }^{4}$ H. Arendt, Rozumienie a Polityka..., dz. cyt., s. 141. 
u wczesnego Heideggera w jego „okresie marburskim” (1924-1928). Arendt przejęła nie tylko to pojęcie, ale również egzystencjalno-fenomenologiczny (ontologiczny) program autora Bycia i czasu przekształcenia filozoficznej tradycji ciągnącej się od Platona i Arystotelesa aż po bezpośrednich nauczycieli Heideggera - H. Rickerta (który wpłynął na M. Webera) i E. Husserla (który znacząco wpłynął na samego Heideggera $)^{5}$. Należy podkreślić, że Arendt przejęła ten naukowo-filozoficzny program nie tyle za pośrednictwem lektury książek, ile dzięki wykładom „ze słuchu”, przy czym na wypracowanie własnej koncepcji potrzebowała trudnej, trwającej dziesięciolecia, konfrontacji z Heideggerem. Nie możemy zagłębić się tutaj w szczegóły jednej z najbardziej zdumiewających recepcji w historii filozofii współczesnej, zaznaczymy tylko, że nie polegała ona na prostym zastąpieniu poglądów nauczyciela poglądami jego uczennicy. Historia ta nie jest obecnie tylko faktem przeszłości, a odwrotnie: coraz bardziej zyskuje na aktualności w świetle współczesnych debat filozoficznych. Dostarczyła ona materiału dla rozległych badań, które przekroczyły granice ", historii filozofii” w zwykłym (tradycyjnym) sensie tego terminu ${ }^{6}$. Z obecnego (historyczno-filozoficznego) punktu widzenia dla zrozumienia koncepcji Arendt istotne są dwa punkty: po pierwsze, niezbędne jest zestawienie "nowej ontologii” Heideggera z tradycją niemieckiej filozofii, a po drugie, należy wskazać powiązania wprowadzonego przez nią pojęcia "przed-rozumienia” $z$ heideggerowskim programem „,hermeneutyki faktyczności", widoczne zwłaszcza w tym jej punkcie, który dotyczy odwrócenia relacji między „naukowym” a "codziennym” (przed-naukowym) rozumem.

W historii hermeneutyki filozoficznej ${ }^{7}$ istotne jest wyodrębnienie trzech podstawowych etapów: Pierwszy związany z imieniem Fryderyka Schle-

${ }^{5}$ Spójna i dokładna analiza kształtowania się myśli Heideggera przed publikacją Bycia i cza$s u$ (1927) została przedstawiona w monografii rosyjskiego historyka idei I. A. Michajłowa.

${ }^{6}$ U. B. Miškinene, Arendt i Hajdegger: popytka sravnitel'nogo analiza fundamental'noj ontologii čeloveka i ontologii politiki, [Arendt i Heidegger: próba analizy porównawczej fundamentalnej ontologii człowieka i ontologii polityki], Moskva, 1990. E. Ettinger, Hannah Arendt and Martin Heidegger, New Haven and London 1995, 132 p.; Hannah Arendt: Twenty Years Later, ed. by Larry May and Jerome Kohn, The MIT Press; Cambridge (Mass.), London (England), 1996, 372 p., s. 179-196, 251-268; D. R. Villa, Arendt and Heidegger: The Fate of the Political, Princeton 1996, s. 329.

${ }^{7}$ P. P. Gajdenko, Proryv $k$ transcendentnomu: Novaâ ontologiâ XX veka, [Przełom ku transcendencji: Nowa Ontologia XX wieku] Moskva 1997, c. 353-390, 391-447; V. L. Mahlin, Vtoroe soznanie, [Drugie poznanie/świadomość] Moskva 2009, c. 190-193, 224-311; I. A. Mihajlov, Rannij Hajdegger: Meždu fenomenologiej i filosofiejžizni, [Wczesny Heidegger: Między fenomenologią a filozofią życia] Moskva 1999; D. K. Hou, Hajdegger 
iermachera (1768-1834), drugi Wilhelma Diltheya (1833-1911), trzeci łączący się z działalnością młodego Heideggera, zwłaszcza z jego projektem „hermeneutyki faktyczności”, do którego nawiązuje Hans-Georg Gadamer w swoim programie społeczno-ontologicznej „kontekstualizacji rozumu”. Na pierwszym etapie "hermeneutyka” (w zasadzie formalna dyscyplina stosowana w badaniach biblijnychi w filologii klasycznej) staje się uniwersalną teorią „rozumienia”, teorią ,interpretacji” tekstu, zorientowaną na zdolność "poprawnego rozumienia mowy innego" (F. Schleiermacher). Na przełomie XIX i XX wieku kategoria interpretacji zostaje wykorzystana przez W. Dilthey'a (biografa F. Schleiermachera) w kontekście jego programu „krytyki historycznego rozumu” 9 . Interpretacja odnosi się u niego do „historycznego świata”, do którego dostęp uzyskujemy za pośrednictwem tekstu jako „czegoś jedynego w swoim rodzaju” ${ }^{10}$. Wreszcie w decydujących latach „zmiany humanistycznego paradygmatu" (Machlin) Heidegger dokonał przełomowej zmiany w filozoficznym i naukowo-humanistycznym sposobie ujmowania kategorii „rozumienia”: ta radykalna zmiana dokonała się początkowo na jego wykładach, a następnie w 31 i 32 paragrafie Bycia i czasu $(1927)^{11}$. Heidegger nie łączy już „rozumienia” i ,interpretacji” z teoriopoznawczą (epistemologiczną) problematyką "nauk humanistycznych”, jak czynił to jeszcze Dilthey, ale pojmuje te kategorie jako fundamentalne, społeczno-ontologiczne cechy Dasein, każdego ludzkiego „bycia tu - oto”. W ten sposób dokonała się prawdziwa „rewolucja w sposobie myślenia”: samo ludzkie bycie skazane jest na rozumienie, każdy „żyje”, tj. istnieje tylko o tyle, o ile „rozumie” rozumie istotę „sposobu bycia” ludzkiego w ogóle (nie człowieka „W ogóle”, ale "każdego" człowieka). Spróbujmy teraz odpowiedzieć na pytanie, jakie znacznie dla naukowo-filozoficznego rozumu może mieć wskazany Heideggerowski przełom w rozumieniu „rozumienia”?

i germenevtičeskij povorot [Heidegger i przewrót hermeneutyczny] // Martin Hajdegger / Pod red. D. Û. Dorofeeva, SPB., 2004.

${ }^{8}$ H.-G. Gadamer, Istina i metod: Osnovy filosofskoj germenevtiki, M.: «Progress», 1988, s. 305-316. [H.-G. Gadamer, Prawda i metoda: Zarys hermeneutyki filozoficznej, tłum. B. Baran, Warszawa 2015].

${ }^{9}$ N. S. Plotnikov, Žizn' i istoriâ: Filosofskaâ programma Vil'gel'ma Dil'teâ, M.: «Dom intellektual'noj knigi>, 2000, s. 13.

${ }^{10}$ O historii hermeneutyki aż do początku XX w. Zob. G. G. Špet, Mysl' i Slovo: izbrannyetrudy [Myśl i Słowo: wybrane prace] / pod red. T. G. Ŝedrinoj, Moskva 2005.

${ }^{11}$ R. Safranski, Hajdegger: germanskij master i ego vremâ [Heidegger: niemiecki mistrz i jego czas] / Per. s nem. V. V. Bibihina. M.: «Molodaâ gvardiâ», 2002. 
Według wczesnego Heideggera ${ }^{12}$ wszystkie nauki zakorzenione są w prenaukowym, codziennym doświadczeniu „bycia tutaj”' ${ }^{13}$. Nasze sądy o świecie nie są możliwe i ważne osobno, same dla siebie, ponieważ opierają się na społeczno-ontologicznym, w sposób istotny historycznym i "faktycznym” fundamencie, decydującym o wyniku i samym procesie myślenia.

Ten fundament - owa "przedmiotowość" "pre-sądów”, "pre-rozumienia”, „pre-rozważań", to znaczy wszystkiego tego, do czego odnosi się zacytowany powyżej fragment z pracy „Rozumienie a polityka” Arendt określa (w swoich amerykańskich wykładach z 1950) mianem judgments i prejudices - „sądów” i „przedsądów”. Trzeba tu zaznaczyć, że źródłem i impulsem słynnej krytyki krytyki negatywnego oświeceniowego konceptu „pre-sądu” w głównej pracy Hansa-Georga Gadamera Prawda i metoda (1960) ${ }^{14}$ jest badawczy program wczesnego Heideggera - tak zwana "hermeneutyka faktyczności”" W Prawdzie i metodzie, bezpośrednio powołując się na swojego nauczyciela, Gadamer pisze o „odkryciu przez Heidegga przedstruktury rozumienia”, która urzeczywistnia swoją „negację negacji” podstawowej negatywnej zasady świadomości i ideologii Oświecenia w pojęciu „pre-sądu”, manifestując tym samym dwuznaczny charakter „tradycji” w historii myślenia i w historii kultury ${ }^{16}$.

Jedynie na tle odkrycia przez Heideggera „prestruktury rozumienia”, tj. na tle ontologizacji klasycznej niemieckiej filozofii możliwe stało się dokonanie tego zwrotu w hermeneutyce polityki Arendt, a ściślej w jej epistemologicznym aspekcie związanym $\mathrm{z}$ pojęciem „wstępnego rozumienia”.

Z drugiej jednak strony, jak sądzimy, Hannah Arendt idzie znacznie dalej niż Heidegger i Gadamer, ponieważ w swych analizach wychodzi poza tzw. „kulturę duchową", „nauki o duchu” i „filozofię”, umieszczając wczesne-

${ }^{12}$ I. A. Mihajlov, Rannij Hajdegger: Meždu fenomenologiej i filosofiej žizni, [Wczesny Heidegger: Między fenomenologią a filozofią życia] Moskva: «Progress-Tradiciâ», 1999, s. 141-147.

${ }^{13}$ M. Hajdegger, Issledovatel'skaâ rabota Vil'gel'ma Dil'teâ i bor'ba zaistoričeskoe mirovozzrenie v naši dni [Badawcza praca Wilhelma Diltheya i walka o historyczny światopogląd w naszych czasach] (per. A. V. Mihajlova) // 2 teksta o Vil'gel'medil'tee: I: G. Špet, II: M. Hajdegger. M., «Gnozis», 1995.

${ }^{14}$ H.-G. Gadamer, Istina i metod: Osnovy filosofskoj germenevtiki, Moskva: «Progress», 1988. [H.-G. Gadamer, Prawda i metoda: Zarys hermeneutyki filozoficznej, tłum. B. Baran, Warszawa 2015].

${ }^{15}$ I. A. Mihajlov, Rannij Hajdegger: Meždu fenomenologiej i filosofiej žizni, [Wczesny Heidegger: Między fenomenologią a filozofią życia] Moskva: «Progress-Tradiciâ», 1999, s. 230-231.

${ }^{16}$ H.-G. Gadamer, Istina i metod: Osnovy filosofskoj germenevtiki, [Prawda i metoda: Zarys hermeneutyki filozoficznej] Moskva: «Progress», 1988, s. 317-388. 
go Heideggera w „niskim” rejestrze polityki, a zatem łącząc jego koncepcję z kategorią „radykalnego zła”, które ma wyjaśniać zjawisko totalitaryzmu $\mathrm{i}$ "totalitarnego myślenia”. Jak pokazano w najnowszych badaniach ${ }^{17}$, ostre odrzucenie przez Arendt „filozofii” nie ma czysto teoretycznego źródła, nie wynika również z biograficznych zaszłości wyznaczonych przez ambiwalentną relację „miłości-nienawiści” do Heideggera ${ }^{18}$. Przy tym należy jednak podkreślić, że sama hermeneutyczno-fenomenologiczna ontologizacja hermeneutyki, samo pojęcie „rozumienia” u Arendt w znacznej mierze określone są przez myśl Heideggera - tyle tylko, że uczennica jest w tym przypadku bardziej radykalna od swojego nauczyciela. Arendt jest bardziej radykalna o tyle, o ile bardziej stanowczo „pożegnała się z filozofią”: rozumieć znaczy dla niej rozumieć „świat”, fenomeny bez oglądania się na filozofię i na metodologię. Oczywiście takie „wyjście” z filozofii poza własne (akademickie) granice było możliwe tylko dzięki „nowej ontologii”.

W późnym artykule Martin Heidegger kończy osiemdziesiąt lat (1969) ${ }^{19}$ Arendt wyjaśnia, dlaczego uważa Heideggera za „ukrytego władcę w królestwie myślenia"20 (za którego także uważała Kanta): jej nauczyciela cechowało „tranzytywne” myślenie, zdolne przenosić się wprost w „sprawę myśli”; Heidegger urzeczywistniał realnie to właśnie, do czego jego nauczyciel E. Husserl tylko nawoływał - do prostego powrotu „do rzeczy samych”. Młody Heidegger najpierw we Freiburgu, a następnie w Marburgu okazał się tym, który na nowo ukazał przeszłość właśnie za pośrednictwem tego, że przerwał

${ }^{17}$ Wśród wspomnianych tutaj prac szczególnie interesująca i głęboka jest książka znanego francuskiego historyka filozofii, fenomenologa Jacquesa Tamino „Służąca z Tracji i zawodowy myśliciel", w której autor podkreśla, że Hannah Arendt przeciwstawiła Heideggera (jako niemieckiego profesora, który postulował „wyjście” filozofii poza własne granice) Marksowi (który odmiennie pojmował postulat przekroczenia filozofii) i doszła do wniosku, że Heidegger stał się ostatecznie „niemieckim mandarynem”, dając się uwieść ideologii narodowego socjalizmu („radykalnego zła”) nie z powodu „politycznego” błędu, ale wskutek „teoretycznych” ograniczeń filozoficznej tradycji, którą sam wcześniej zakwestionował.

${ }^{18}$ Echa tej dwuznacznej relacji słyszalne są w pracy z 1945 roku, pt. „Co to jest egzystencjalizm”, w której Jaspers przeciwstawia się Heideggerowi, rzec można, jako „dobro” „złu”. Po spotkaniu Arendt z Heideggerem (1950) rozpoczął trudny proces pojednania między uczennicą a nauczycielem. Arendt odstąpiła od publicznej krytyki Heideggera. W jubileuszowym artykule z końca lat 60. wysunęła na pierwszy plan znaczenie Heideggera w filozofii XX w., spychając w cień chwile niezgodności, punkty sporne i kontrowersje.

${ }^{19}$ H. Arendt, Martin Heidegger kończy osiemdziesiąt lat, [w:] tenże, Ludzie w mrocznych czasach., przeł. Mieczysław Godyń, Andrzej Kopacki, Henryk Krzeczkowski, Agnieszka Pokojska, Ewa Rzanna, Anna Wołkowicz, Gdańsk 2013, s. 173-185.

${ }^{20}$ Tamże, s. 176. 
nić tradycji. W technicznym sensie decydujące było to, że dla przykładu wykłady poświęcone Platonowi nie służyły bynajmniej wyjaśnieniu jego teorii, zamiast tego Heidegger przez cały semestr analizował wybrany dialog krok po kroku, jak gdyby nie istniała żadna tysiącletnia tradycja czytania Platona, sprowadzając zawarte w nim idee do codziennej problematyki. Dzisiaj tego rodzaju praktyka spowszedniała nam, jednakże do czasów Heideggera nikt nie postępował w ten sposób wobec dzieł klasyków ${ }^{21}$. Nikt więc nie stosował nowej metodyki "przechodniej”, tranzytywnej analizy „rzeczy samych”, to znaczy, fenomenologiczno-hermeneutycznej praktyki czytania filozoficznych tekstów, czy - jak wyraża się Arendt - praktyki „myślącego czytania”22.

Nie będzie zatem przesadą stwierdzenie, że badawczy program Arendt stanowi „przechodnią” hermeneutykę „myślącego czytania”, ale już nie tylko i nie tyle filozoficznych tekstów, ile „myślenia” o samej tradycji niejako z dwóch „perspektyw”: z punktu widzenia przeszłości prowadzącej do naszej współczesnościi z punktu widzenia naszej współczesności, która ponownie kieruje nas ku przeszłości i odkrywa tę przeszłość zgodnie z logiką starej hermeneutycznej zasady „koła rozumienia”, ale tak, aby zaktualizowany sens stał się częścią współczesnej ontologizacji hermeneutyki ${ }^{23}$.

Uściślijmy "przewrotny” charakter interesującego nas tutaj stanowiska Arendt, które kontynuuje hermeneutyczną tradycję w filozofii kosztem „pożegnania z filozofią" i przejściem do „teorii polityki” (której specjaliści w dziedzinie „politycznej teorii” często odmawiają logicznego charakteru). Hermeneutyczna fenomenologia "myślącego czytania” odnosi się do historycznych fenomenów, rozpatruje je w społeczno-politycznej „faktyczności” - niezależnie od tego, czy będzie to "faktyczność" bycia „w-świecie” antycznej polis, w której myśli Platon albo Arystoteles, czy sytuacja „w-świecie” epoki Oświecenia, w której myśli Kant, czy też sytuacja końca czasów współczesnych (XX w.) - sytuacja „mrocznych czasów”. W przeciwieństwie do pracy Czym jest filozofia egzystencji?, w swoich późnych dziełach (po „pojednaniu”

\footnotetext{
${ }^{21}$ Tamże.

22 Tamże.

${ }^{23}$ G.-G. Gadamer, Aktual'nost' prekrasnogo, Moskva, «Iskusstvo», 1991, s. 72-82.

V. L. Mahlin, Vtoroe soznanie, [Drugie poznanie/świadomość] Moskva, «Znak», 2009, s. 229-334. H-G. Gadamer, Aktualność Piękna, przeł. Krystyna Krzemieniowa, Warszawa 1993.
} 
z Heideggerem w życiu osobistym ${ }^{24}$ ), Arendt nigdy nie pozwalała sobie na gwałtowną, bezpośrednią polemikę z nauczycielem; jednakże ta polemika przyjmowała bardziej ukrytą formę jakby poważnego uznania dla poprawnego politycznie „przewrotu” myśli nauczyciela. W tym kontekście za najciekawszy przykład takiego „przewrotu” może służyć przedmowa Arendt do książki Ludzie w mrocznych czasach $(1968)^{25}$, w której autorka cytuje metaforyczny, a w kontekście społeczno-politycznym znamienny ustęp z Bycia i czasu: „Opinia publiczna zaciemnia wszystko” ${ }^{26}$. Powołując się na heideggerowskie wypowiedzi o „tłumie”, o „gadaninie”27, oraz „bardziej ogólnie, o tym wszystkim, co niezakryte i niechronione prywatnością Siebie, pojawia się w sferze publicznej!”28. Arendt pisze: „Według Heideggera jedynym sposobem ucieczki od »niepojmowalnej trywialności« tego zwykłego, codziennego świata jest wycofanie się w samotność, którą sferze politycznej przeciwstawiają filozofowie, począwszy od Parmenidesa i Platona" ${ }^{29}$.

Z taką właśnie eskapistyczną tradycją polemizuje Arendt. „Opinia publiczna” nie tylko zaciemnia („przytłacza” albo „zasłania”) światło prawdy, ale również ujawnia prawdę. Ponadto tylko w "mrocznych czasach” publiczność, a ściślej sfera publiczna (the public realm) „rozjaśnia egzystencję”, jak powiedziałby inny nauczyciel Arendt - Karl Jaspers. Należy więc odnieść się do "ogólnego codziennego świata” nie z pozycji „zawodowego filozofa”, nie „przedmiotowo”, ale hermeneutycznie, „przechodnio” właśnie, jak uczył sam młody Heidegger. Bardzo charakterystyczna jest w tym kontekście metodologiczna orientacja Arendt przejawiająca się w nadaniu nowego znaczenia pojęciu „publiczności” („światłej publiczności”).

„Nie interesuje nas tutaj - pisze Arendt w cytowanym już wstępie do Ludzi w mrocznych czasach - filozoficzna wartość owych analiz (moim zdaniem nie-

\footnotetext{
${ }^{24}$ O perypetiach relacji między Arendt a Heideggerem po wojnie pisał: R. Safranski, Hajdegger: germanskij master i ego vremâ [Heidegger: niemiecki mistrz i jego czas] / Per.s nem. V.V. Bibihina. Moskva: «Molodaâ gvardiâ», 2002, s. 487-508.

${ }^{25} \mathrm{H}$. Arendt, Lûdi v temnye vremena (per. s angl. i nem. G. Daševskogo, B. Dubina), Moskva. «Moskovskaâ škola političeskih issledovanij», 2003. Cyt. Za: H. Arendt, Ludzie w mrocznych czasach, Gdańsk 2013.

${ }^{26}$ M. Hajdegger, Bytie i vremâ, Moskva 1997, s. 15; M. Heidegger, Bycie i czas, przeł. B. Baran, Warszawa 1994, s. 181.

${ }^{27}$ M. Heidegger, Bycie i czas, s. 227 i nast.

${ }^{28}$ H. Arendt, Ludzie w mrocznych czasach, s. 15.

${ }^{29}$ Tamże.
} 
zaprzeczalna) ani stojąca za nimi tradycja filozoficznej refleksji, ale wyłącznie pewne podstawowe doświadczenie tamtego czasu oraz ich opis pojęciowy"30.

Jak widzimy, w dociekaniach Heideggera Arendt interesują nie tylko same myśli nauczyciela, z którymi de facto jest ona całkowicie zgodna, ale też tradycja tych myśli w historii filozofii ${ }^{31}$. W duchu "nowej ontologii” Heideggera Arendt interesuje się „doświadczeniem epoki”, hermeneutyczną faktycznością doświadczenia, która nie sprowadza się ani do osobowości myślącego, ani do tradycji, w jakiej jest on zakorzeniony. Zauważmy przy tej okazji, że tradycyjne historiozoficzne analizy koncentrują się głównie w tych dwóch punktach - na „autorze”, którego trzeba zrozumieć, i na „tradycji”, w której kontekście powinna „rozjaśnić się" indywidualność autora. Doświadczenie „faktyczności” epoki ukazuje w całkowicie nowy sposób myśliciela, jego myślenie i „czasowość" samej tradycji. W taki sposób dokonuje się wyjście poza granice „czysto” retorycznego, „czysto” teoretycznego i ideologicznego myślenia (i rozumienia tekstu). „Wyjście” to wymaga jednak podjęcia nowego sporu (u Arendt byłby to dożywotni i zasadniczy spór z Heideggerem), który nie opiera się na polemicznym „nie”, lecz na pojednawczym „tak”. Według Arendt musimy bronić istotności, niezbędności „ogólnego codziennego świata" jako warunku możliwości wszystkiego, co jest indywidualne, niepowtarzalne i „prywatne”, nie wykluczając myślenia myśliciela. W analizowanej przedmowie do Ludzi w mrocznych czasach Arendt chce powiedzieć, że również to oczywiste światło, które rzuca prawdziwe, "przechodnie” myślenie, samo staje się odbiciem doświadczenia epoki.

Przełożyła i opracowała Aleksandra Kondrat Uniwersytet Mikołaja Kopernika, Toruń, Polska moskwa.ros@gmail.com

\footnotetext{
${ }^{30}$ Tamże.

${ }^{31}$ Filozoficzną tradycję myślenia „sam na sam” szczegółowo rozpatrywała Arendt (poza niedokończoną dwutomową książką „Życie umysłu”) w kursie wykładów „Problem działania i myślenia po rewolucji francuskiej", przeczytanym przez nią na uniwersytecie Notre-Dame w 1954 roku. Rękopis, zredagowany przez samą Arendt, opublikowany dopiero w 1990 r. pod (autorską) nazwą „Filozofia a polityka”.
} 


\section{Bibliografia}

Arendt H., Lûdi v temnye vremena (per. s angl. i nem. G. Daševskogo, B. Dubina), Moskva. «Moskovskaâ škola političeskih issledovanij», 2003.

Arendt H., Hajdeggeru - vosem'desât let // Voprosy filosofii, 1998, № 1, s. 126-134.

Gadamer H.-G., Aktual'nost' prekrasnogo, Moskva, «Iskusstvo», 1991.

Gadamer H.-G., Istina i metod: Osnovy filosofskoj germenevtiki, Moskva: «Progress», 1988.

Gajdenko P. P., Proryv k transcendentnomu: Novaâ ontologiâ XX veka, Moskva: «Respublika», 1997.

Kurabcev V. L., Vopros o Dasein // Vestnik Moskovskogo gosudarstvennogo oblastnogouniversiteta. Seriâ «Filosofskienauki», 2013, № 3, s. 51-55.

Mahlin V. L., Vtoroe soznanie, Moskva, «Znak», 2009, 626 c.

Mihajlov I. A., Rannij Hajdegger: Meždu fenomenologiej i filosofiej žizni, Moskva: «Progress-Tradiciâ», 1999, 284 s.

Miškinene Û. B., Arendt i Hajdegger: popytka sravnitel'nogo analiza fundamental'noj ontologii čeloveka i ontologii politiki, Moskva: MGU, 1990.

Plotnikov N. S., Žizn' i istoriâ: Filosofskâ̂ programma Vil'gel'ma Dil'teâ, Moskva: «Dom intellektual'noj knigi», 2000, 226 s.

Safranski R., Hajdegger: germanskij master i ego vremâ / Per. s nem. V. V. Bibihina, Moskva: «Molodaâ gvardiâ», 2002, 612 s.

Hajdegger M., Bytie i vremâ. Moskva: “AdMarginem”, 1997, 446 s.

Hajdegger M., Issledovatel'skaâ rabota Vil'gel'ma Dil'teâ i bor'ba za istoričeskoemirovozzrenie v $n$ (per. A. V. Mihajlova) // 2 teksta o Vil'gel'me Dil'tee: I: G. Špet, II: M. Hajdegger. Moskva, «Gnozis», 1995, s. 137-191.

Hou D. K., Hajdegger i germenevtičeskij povorot // Martin Hajdegger / Pod red. D. U,,Dorofeeva, SPB., 2004, s. 275-301.

Špet G. G., Mysl' i Slovo: izbrannye trudy / Pod red. T. G. Ŝedrinoj. M.: ROSSPÈN, 2005, $686 \mathrm{~s}$.

Arendt H., Essays in Understanding, 1930-1954: Formation, Exile, Totalitarianism, ed. and with an intr. by Jerome Kohn. N.Y., 1994, 458 p.

Arendt H., Philosophy and Politics, Social Research, Vol. 57, No. 1 (Spring 1990), p. 73-103.

Arendt H., Ludzie w mrocznych czasach, przeł. Mieczysław Godyń, Andrzej Kopacki, Henryk Krzeczkowski, Agnieszka Pokojska, Ewa Rzanna, Anna Wołkowicz, Gdańsk 2013.

Ettinger E., Hannah Arendt and Martin Heidegger, New Haven and London 1995, $132 \mathrm{p}$.

Hannah Arendt: Twenty Years Later, ed. by Larry May and Jerome Kohn, The MIT Press; Cambridge (Mass.), London (England) 1996, 372 p. 
Heidegger M., Bycie i czas, przeł. Bogdan Baran, Warszawa 1994.

Gadamer H.-G., Aktualność piękna, przeł. Krystyna Krzemieniowa, Warszawa 1993. Taminiaux, J., The Thracian Maid and the Professional Thinker: Arendt and Heidegger / Trans. and ed. by Michael Gendre, New York, 1997, 217 p.

Villa D. R., Arendt and Heidegger: The Fate of the Political, Princeton, 1996, 329 p.

Villa D. R., The Banality of Philosophy: Arendt on Heidegger and Eichmann // Hannah Arendt: Twenty Years Later, ed. by Lary May and Jerome Kohn, Cambridge (Mass.) and London 1997, p. 179-196.

\section{Abstract \\ „Transitive” Political Hermeneutics (H. Arendt and M. Heidegger)}

The article is an attempt to analyze Arendt's term preliminary understanding (preliminary understanding) in order to come to an understanding of Arendt's hermeneutics, i.e. to understand, to the extent possible, the problem of knowledge in Arendt's manner, relying on the historical and philosophical background of her thoughts, and as a "preliminary understanding ,is associated with the" hermeneutics of factuality "of Heidegger, how the research program Arendt became virtually" transitive "hermeneutics" thinking in the policy being.

Key words: hermeneutics, phenomenology, existentialism, perception, preliminary understanding, hermeneutics factual 